\title{
QUE HISTÓRIAS OS MEMES PODEM NOS CONTAR? PEDAGOGIAS CULTURAIS E CURRÍCULO
}

\section{- CLÍCIA COELHO}

Universidade Federal de Goiás

RESUMO Neste artigo abordamos as Pedagogias Culturais como possibilidades de materialização dos processos de aprendizagem que decorrem de concepções pós-críticas de currículo educativo. No texto, focamos a emergência do "meme" de internet, como um dispositivo capaz de acionar memórias e estimular a criação de narrativas abertas, que provocam outros olhares sobre o trânsito/fluxo entre imagens, cotidiano, pedagogias e currículo.

Palavras-chave: "Meme" de internet. Pedagogias culturais. Currículo.

WHAT STORIES THE MEMAS CAN TELL US? CULTURAL PEDAGOGIES AND CURRICULUM

In this article we approach Cultural Pedagogies as a possibility of materialization of the learning processes that derive from post-critical conceptions of educational curriculum. The text focuses on the emergence of the internet 'meme' as a device capable of triggering memories in order to stimulate the creation of open narratives that provoke other glances about the transit/flow between images, everyday life, pedagogies and curriculum.

Keywords: Internet “Meme". Cultural pedagogies. Curriculum.

\section{RESUMEN}

\section{¿QUÉ HISTORIAS LOS MEMES PUEDEN CONTAR? PEDAGOGÍAS CULTURALES Y CURRICULUM}

En este artículo abordamos las Pedagogías Culturales como posibilidad de materialización de los procesos de aprendizaje que se derivan de concepciones post-criticas de currículo educativo. En el texto enfocamos la emergencia del 'meme' de internet como dispositivo capaz de accionar memorias y estimular la creación de narrativas abiertas que provocan otras miradas sobre el tránsitos/flujo entre imágenes, cotidianidad, pedagogías y currículo.

Palabras clave: "Meme” de Internet. Pedagogías culturales. El currículo. 


\section{Considerações iniciais}

Pesquisar os diversos modos como nos construímos sujeitos - homem; mulher; professor; aluno; consumidor etc. - colocando em perspectiva a ação dos artefatos culturais no contexto contemporâneo, tem sido tema e foco de interesse recorrente em investigações voltadas para os campos de estudos da arte, da cultura visual e da educação (DIDI-HUBERMAN, 2012; AGUIRRE, 2011; SILVA, 2000). Nesse sentido, as discussões sobre as Pedagogias Culturais, fundamentadas especialmente nos Estudos Culturais em Educação (ECE), têm gerado importantes aportes teóricos para a compressão da produtividade da cultura como expediente pedagógico.

Silva (2000) concebe as Pedagogias Culturais como artefatos e modos de operar a educação por múltiplos processos, inclusive aqueles que abrangem a educação escolar, mas não se limitam a ela. As Pedagogias Culturais abrangem "[...] qualquer instituição ou dispositivo cultural que, tal como a escola, esteja envolvido - em conexão com relações de poder - no processo de transmissão de atitudes e valores" (SILVA, 2000, p. 89). De acordo com essa compreensão, além das instituições educativas escolarizadas, mídias digitais - escritas, faladas, visuais - como um filme, uma peça publicitária, um musical ou uma exposição, em museu ou em galeria de arte, são pedagogias que difundem informações e conhecimentos por meio de processos subjetivos/afetivos de aprendizagem.

1 Campo de estudo que investiga as contribuições dos Estudos Culturais para a Educação, construindo conexões entre cultura e poder; e enfatizando trabalhos que visem desafiar as fronteiras disciplinares, mediante estudos que exploram a transdisciplinaridade ou celebram a pós-disciplinaridade. Os "Estudos Culturais em Educação constituem uma ressignificação e/ou uma forma de abordagem do campo pedagógico em que questões como cultura, identidade, discurso e representação passam a ocupar, de forma articulada, o primeiro plano da cena pedagógica". (COSTA; SILVEIRA; SOMMER, 2003, p. 54)
A problematização de um tema dessa natureza torna-se imprescindivel, no contexto das transformações tecnológicas, sobretudo, nos tempos de convergência digital que estamos vivendo. A sobrecarga de artefatos culturais que invadem e se espraiam no cotidiano educativo formal tem provocado tensões crescentes nas noções de currículo, exigindo que estejamos atentos ou em sintonia com essa "nova" demanda social.

A discussão proposta neste texto surgiu no cotidiano da sala de aula, mais especificamente na disciplina Arte e Cultura Visual, no curso de Licenciatura em Artes Visuais da Universidade Federal de Goiás (UFG). Debatíamos sobre os processos de aprendizagem que acontecem no entrelugar (SANTIAGO, 2006; YÚDICE, 2005), ou seja, num espaço cambiante e ambíguo, uma espécie de "dentro/fora" das instituições formais de educação e que, devido às suas características informais, extrapolam e rompem concepções/compreensões de currículo e, em decorrência, a atuação docente. De acordo com Miranda (2015, p. 160), "as aprendizagens que podemos gerar para uma educação que tenha a ver com a arte contemporânea e a cultura visual devem reconhecer as formas pelas quais produzimos conhecimentos sobre o mundo e sobre nós mesmos".

Como parte da proposta da aula, comentávamos sobre uma pesquisa de doutorado que está sendo desenvolvida no Programa de PósGraduação em Arte e Cultura Visual - PPGACV/ UFG. A investigação tem como foco os discursos deflagrados pelos "memes" de internet como dispositivos de aprendizagem e difusores de significados que, cada vez mais, operam fora do currículo formal, mas não apartados dele.

A discussão ficou mais acalorada quando, durante o debate, surgiu a questão da reformulação do currículo do Ensino Médio, ${ }^{2}$ apro-

2 A Lei no 13.415, de 16 de fevereiro de 2017, altera as leis no 9.394 , de 20 de dezembro de 1996, que estabelecem as diretrizes e bases da educação nacional, e a Lei no. 
vada pelo Governo Federal, em 16 de fevereiro de 2017. As querelas sobre as mudanças referentes à oferta da disciplina "arte" ganharam ênfase, ao analisarmos as razões pelas quais, na primeira versão da proposta de lei (Medida Provisória no. 746/2016), a arte deixou de ser um componente curricular obrigatório. Posicionamentos contrários e a favor das mudanças propostas pelo Governo Federal foram sendo apresentados, defendidos e contra-argumentados, à medida que os alunos debatiam o assunto. A discussão mostrou-se muito pertinente e, em conjunto, decidimos que daríamos continuidade ao assunto na aula seguinte, visto que o tempo já havia esgotado.

Combinamos, também, que além da continuidade do debate sobre a reformulação do Ensino Médio, iríamos produzir narrativas escritas, orais e/ou visuais, sobre acontecimentos ordinários, sobre histórias de vida, pessoais ou não, deflagradas a partir de "memes" de internet que suscitassem, em suas representações imagético-discursivas, dilemas e embates decorrentes de visões de currículo educativo afastadas das demandas e necessidades contemporâneas. Esse planejamento colaborativo, concebido e construído em conjunto com os(as) alunos(as), sob o guarda-chuva teórico da Cultura Visual e das Pedagogias Culturais, resultou na discussão que relatamos a seguir.

\section{A dimensão pedagógica do meme}

O fenômeno "meme" ganhou destaque no meio científico, a partir das ideias de Richard Dawkins, publicadas no livro The selfish gene

11.494, de 20 de junho 2007, que regulamenta o Fundo de Manutenção e Desenvolvimento da Educação Básica e de Valorização dos Profissionais da Educação, a Consolidação das Leis do Trabalho - CLT, aprovada pelo Decreto-Lei no 5.452, de 10 de maio de 1943, e o Decreto-Lei no. 236, de 28 de fevereiro de 1967; revoga a Lei no 11.161, de 5 de agosto de 2005; e institui a Política de Fomento à Implementação de Escolas de Ensino Médio em Tempo Integral.
(O gene egoísta, 2007), em 1976. Fazendo uma analogia com o campo da genética, o autor desenvolve uma discussão sobre a teoria social darwiniana dando-nos a ideia da existência de coerências e simetrias subjacentes às relações sociais, a partir de uma seleção natural daquilo que compreendemos como produtos culturais. Segundo o autor, "memes" são replicadores culturais análogos àqueles da transmissão genética que, assim como no processo de reprodução genética, podem determinar um tipo de evolução a partir da ideia de preservação e continuidade de si.

Ao propor uma definição para esse elemento/fenômeno que denominou "meme", Dawkins (2007, p. 148, grifos do autor) explica o seguinte:

Precisamos de um nome para o novo replicador, um substantivo que transmita a ideia de uma unidade de transmissão cultural, ou uma unidade de imitação. 'Mimeme' provém de uma raiz grega adequada, mas quero um monossílabo que soe um pouco como 'gene'. Espero que meus amigos helenistas me perdoem se eu abreviar mimeme para meme. Se servir como consolo, pode-se, alternativamente, pensar que a palavra está relacionada a 'memória', ou à palavra francesa même.

Os "memes" seriam ideias materializadas ou não, potencialmente replicáveis e transmitidas por meio de processos imitativos que, por sua natureza seletiva, reconfiguram-se na medida em que necessitam se fixar. No entanto, é importante entender que essa fixação não é estável e muito menos perene, ela se mantém enquanto houver uma lógica oportuna que a configure e situe como faceta cultural.

Ao consideramos os "memes" de internet como dispositivos de aprendizagem nos amparamos em ideias que expandem a discussão desse fenômeno para o campo da crítica cultural. Limor Shifman (2014) compreende os "memes" como fatores culturais da contemporaneidade, que vigoram na dinamicidade 
das Tecnologias de Informação e Comunicação (TIC), nas operações matemáticas da internet 2.0, mas que extrapolam esses limites, provocando impactos na vida cotidiana de usuários mais ou menos conectados. A autora entende que não existe uma separação rígida entre o que passamos a chamar de cultura real e cultura virtual.

Segundo Shifman (2014), os "memes" de internet são ideias materializadas em palavras, imagens e sons, numa fusão intermídia com alto poder de difusão e manipulação, sobretudo no contexto das redes sociais, pela interatividade dos internautas. O "meme", portanto, não é uma representação em si, mas uma ideia replicada, viralizada e reconfigurada a cada situação/ambiência na qual é utilizada/empregada.

Pensando o "meme" nesses formatos, podemos associá-los aos estudos das pedagogias culturais que nos convidam a ampliar as nossas concepções sobre os processos de ensino e aprendizagem para contextos que extrapolam o âmbito escolarizado, visto que a expressão pedagogia é entendida "como conjunto de saberes e práticas relacionadas com o governamento de si e dos outros" (NOGUERA-RAMÍREZ, 2009, p. 27), ou seja, como prática social de assujeitamento, mas, também, de resistência.

Noguera-Ramírez (2009, p. 230, grifos do autor) reforça essa associação - “memes"/pedagogias culturais - ao argumentar que "se a Modernidade se inaugurou, nos séculos XV e XVI como uma 'sociedade de ensino', hoje ela estaria se fechando sob a forma de uma 'sociedade de aprendizagem'", pois:

a aprendizagem é hoje a forma do governamento pedagógico, o governamento não mais do cidadão, mas do 'aprendiz permanente', do homo discens. Aprender ao longo da vida, aprender a aprender é a divisa do governamento contemporâneo. Estamos sendo compelidos a nos comportar como aprendizes permanentes, que moramos em sociedades de aprendizagem ou cidades educativas. (NOGUERA-RAMÍREZ, 2009, p. 231, grifos do autor)

Pensar a educação a partir dessa perspectiva fortemente afetada pelas transformações emergentes da contemporaneidade nos ajuda a conceber e aprender a construir outros espaços de aprendizagem, que se deslocam e se reconfiguram sempre que necessário, ampliando as nossas noções de educação e currículo, porque:

[a]s aprendizagens acontecem mediante processos subjetivos que não são visíveis, nem palpáveis. Estes processos acontecem no corpo, envolvendo as práticas sociais aprendidas em contextos, formas de relação instaladas no nosso modo de ser e viver e que, portanto, formam parte do nosso repertório cotidiano de participação em diversas comunidades. (MARTINS apud MIRANDA, 2015, p. 150)

No âmbito acadêmico, discussões sobre os conceitos de currículo oculto (APPLE, 2006) e pedagogia invisível (BERNSTEIN, 1984) têm sido feitas desde a década de 60 do século passado, anunciando a importância da adoção de pedagogias que não se limitassem às práticas escolares propriamente institucionalizadas e pautadas na inflexão de currículos fixos.

Para Apple (2006), com o passar do tempo, os interesses sociais, determinados por contextos históricos específicos, vão se transformando em ideias e visões de mundo que são de alguma forma incorporadas aos currículos oficiais. Essas ideias circulam pelas relações sociais e promovem processos de agenciamento que, embora ocultos, provocam a instauração de hegemonias - ações por meio das quais acontecem a inculcação de "verdades" e a internalização de valores dominantes na sociedade.

Para Bernstein (1984), o conceito de pedagogia invisivel, ainda hoje utilizado na educação formal, estabelece-se através de regras 
implícitas do "jogo" que não são conhecidas pelos alunos. Esse conceito se estabelece, também, pela complexidade das teorias de aprendizagem que norteiam e direcionam o trabalho dos professores. Além disso, na maioria dos casos, os professores estão pressionados por um cipoal de normas e excessivas demandas burocráticas, que drenam a vitalidade pedagógica e depreciam o processo educativo como espaço de relações dialógicas entre professores, alunos e contexto.

Os Estudos Culturais, assim como os Estudos da Cultura Visual, adicionam a esses processos pedagógicos a compreensão de currículo como uma prática social em constante transformação, contrariando a noção de currículo estruturado como receitas a serem seguidas (NASCIMENTO, 2011). A Cultura Visual "denota uma pedagogia crítica, que não sugere nem promove uma metodologia ou pedagogia unificada e específica, ou ainda, que indique um currículo exclusivo" (DIAS, 2014, p. 52).

Assim como Apple (2006) e Bernstein (1984), os estudiosos da Cultura Visual também estão preocupados com as relações de poder existentes no fazer/construir/vivenciar currículos educativos e com as diferentes concepções de agenciamento, oculto e/ou invisivel. A Cultura Visual fundamenta-se no princípio de que os processos de agenciamento e subjetivação dos sujeitos estão presentes sem máscaras na farta circulação de imagens emergentes na contemporaneidade, daí a urgente necessidade de problematizá-las.

Assim, a compreensão pedagógica do "meme" de internet como um artefato cultural está substanciada nos princípios que fundamentam os estudos da Cultura Visual, visando, de maneira transdisciplinar e até mesmo adisciplinar, transitar pelas interfaces das mídias digitais para provocar tensão, denunciar, ressignificar visões e práticas educativas pautadas em ideias curriculares que ainda se man- tém, na atualidade, travestidas de propostas inovadoras.

\section{Narrativas visuais e práticas curriculares "memificadas"3}

Ao abordar e discutir os memes de internet, reconhecemos seu potencial de narrar/explorar subjetividades, que impactam a construção de identidades, e o modo como estes estão imbricados como parte da experiência dos indivíduos no mundo contemporâneo. Ao se materializarem em imagens e/ou visualidades, suas características constitutivas ganham força "para provocar fissuras semânticas nos modos de organizar e interpretar discursos/ textos/signos e imagens, rompendo os limites das 'linguagens' e desestabilizando convenções, ao mesticizar figurações da voz, do corpo, da vida ou da morte" (MARTINS, 2009, p. 34, grifo do autor).

Narrativas visuais têm sido veiculadas predominantemente em contextos/ambientes tecnológicos sendo o principal deles a rede mundial de computadores. Essa característica das narrativas e, por extensão, dos memes, tem grande alcance porque promove tanto o consumo quanto a produção. Vale lembrar que o usuário da Web consome, mas também produz conteúdos (PRADA, 2008). A versatilidade dos softwares e a disponibilidade de aplicativos de fácil operacionalidade têm mudado o nosso comportamento diante das interfaces das Tecnologias de Informação e Comunicação (TIC). Basta navegar em uma rede social on-line, como o Facebook, para nos depararmos com muitos exemplos dessas narrativas sendo utilizadas para diversos fins. As narrativas visuais (figura 1), a seguir, são exemplos dessa proliferação.

3 Relativo ao processo de replicagem e viralização característico do fenômeno meme atribuído às narrativas visuais veiculadas no contexto da internet. 
Figura 1 - Exemplos de narrativas visuais que viraram memes de internet.

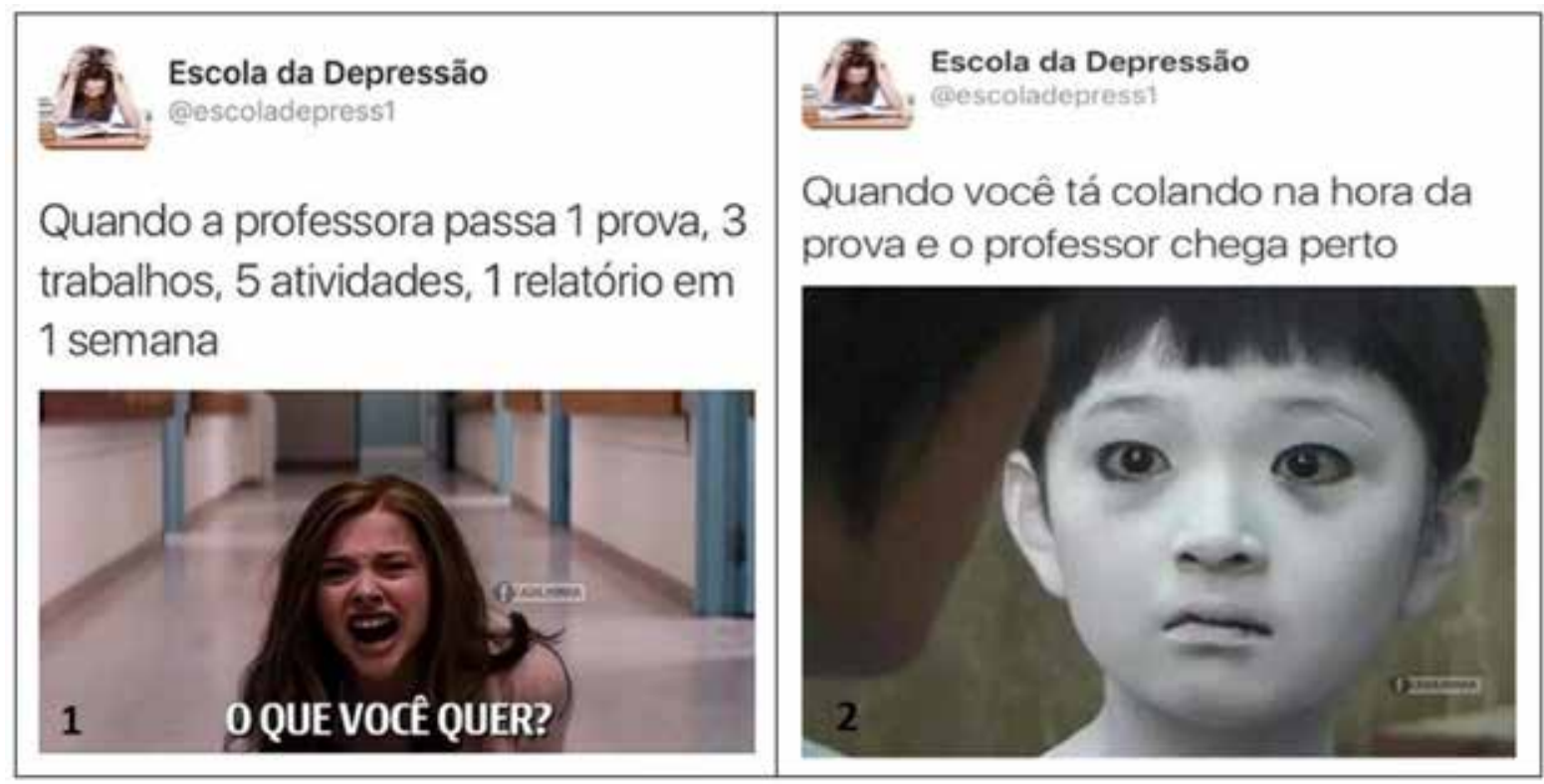

Fonte: Disponivel em:<https://www.facebook.com/pg/EscolaDepress1/photos/?ref=page internal>.

Acesso em: 04 ago. 2017.

Ao examinar essas narrativas seguindo as pistas imagético-discursivas que elas fornecem e analisar algumas de suas interpretações, a partir de um repertório cultural acumulado, fica evidente que ambas satirizam práticas do cotidiano escolar, configuradas por mixagens que agrupam cenas de filmes, desenhos, legendas e outras marcas tipográficas. 0 quadrinho 1, por exemplo, aborda questões relacionadas às inúmeras atribuições delegadas aos estudantes para o cumprimento de atividades avaliativas das disciplinas. Sublinhamos a palavra disciplina para ressaltar a força que os componentes curriculares exercem sobre os jovens, representados na narrativa pela figura de uma adolescente estressada e descontente com a sobrecarga disciplinar exigida na escola. Ela grita uma frase de efeito para questionar o sujeito oculto da cena, que pode ser o professor, o pai, a mãe ou o próprio internauta, expectador e receptor da mensagem.

A narrativa 2 retrata uma prática muito corriqueira nos dias de prova nas escolas. Destacamos a palavra prova para salientar a força que esse discurso pedagógico, moldado por uma visão tradicional de ensino, ainda exer- ce nas instituições escolares e na educação contemporânea. Estudantes são postos à prova para demonstrar o que aprenderam nas disciplinas, sob pena de serem reprovados. A sátira mostra o aluno pálido ao ser flagrado pelo professor, aquele sujeito/autoridade que fabrica e aplica a prova, e cujo resultado, com frequência, é visto como um tipo de troféu, que pode ou não ser obtido, dependendo do grau de aprendizado dos conteúdos que estão sendo avaliados.

Sabemos que são diversas as possibilidades interpretativas dessas narrativas, do mesmo modo que não existe uma única maneira de abordar ou falar sobre elas. 0 contexto no qual elas estão inseridas, associado às informações e conhecimentos que acumulamos via experiência docente/discente, podem proporcionar interpretações divergentes ou até mesmo contraditórias porque o substrato da imagem não obedece a regimes lineares rígidos para a construção de sentidos e significados.

A relação entre aprendizagem e reflexividade autobiográfica ainda é vista como algo estranho à formação dos sujeitos aprendizes, impedindo que os alunos, como narradores, se 
redescubram e se reinventem. Goodson (2007), ao tratar desta questão, fala da importância da "aprendizagem narrativa" e do "capital narrativo", enfatizando que a aprendizagem sempre é um tipo de resposta a situações concretas, ou seja, situações reais. Como professores, convivemos com os acontecimentos do cotidiano escolar e a interpretação dessas cenas, momentos, ocorrências, que podem nos levar a reflexões sobre o currículo e, sobretudo, sobre a profissão docente, porque tais acontecimentos acionam as nossas memórias narrativas sobre as práticas sociais que vivemos.

Ao se referir à memória narrativa, Souza (2007, p. 4) destaca que:

a memória é escrita num tempo, um tempo que permite deslocamento sobre as experiências. Tempo e memória que possibilitam conexões com as lembranças e os esquecimentos de si, dos lugares, das pessoas e das dimensões existenciais do sujeito narrador.

Assim, acionar essas lembranças nos ajuda a reconfigurar as posições daqueles que ensinam em relação àqueles que aprendem, pois, ao mesmo tempo em que aprendemos, também nos transformamos como parte de um processo formativo que acontece de maneira coletiva. As experiências vividas importam, mas, para além delas, o modo como são simbolizadas pela ação das narrativas, como são contadas e recontadas para si e para o outro, ou seja, para o grupo, impactam a constituição da subjetividade. As narrativas, como construção e ação humanas, são parte inerente à história dos indivíduos, constituindo uma espécie de representação mental. Nesse sentido, Souza (2007, p. 4) salienta que:

é evidente que a memória inscreve-se como uma construção social e coletiva e vincula-se às aprendizagens e representações advindas da inserção do sujeito em seus diferentes grupos sociais. A relação entre memória e esquecimento revela sentidos sobre o dito e o não-dito nas histórias individuais e coletivas dos sujeitos, marca dimensões formativas entre experiências vividas e lembranças que constituem identidades e subjetividades, potencializando apreensões sobre as itinerâncias e as práticas formativas. 0 não-dito vincula-se às recordações e não significa, necessariamente, o esquecimento de um conteúdo ou de uma experiência.

Assim, as narrativas visuais permitem rememorar e contingenciar algumas práticas curriculares vigentes, consideradas organismos socio-históricos, como de fato o são. Esse exercício nos leva a "olhar pelo retrovisor" e nos ajuda a refletir sobre modos pretéritos de pensar, de construir e experienciar a práxis educativa, a partir de discursos pedagógicos que se estabeleceram anteriormente, mas que ainda persistem no presente, assim como um meme que "pega", viraliza, reconfigura-se e fica latente no repertório e no "gosto" dos usuários. Esta é uma relação/associação que consideramos pertinente, sobretudo, pelo potencial de agenciamento que os discursos pedagógicos, assim como os memes, podem deflagrar.

Relatos de experiências discentes que questionam e denunciam visões de currículo

As quatro narrativas denominadas "meme causos", que serão apresentadas a seguir, foram contadas na primeira pessoa por estudantes $^{4}$ do curso de Licenciatura em Artes Visuais, que aceitaram o desafio de problematizar concepções de currículo educacional e seus reflexos na vida cotidiana a partir de "memes" de internet. Ao discuti-las, ou interpretá-las, partimos do princípio de que:

4 Identificamos os(as) estudantes usando apenas as iniciais de seus nomes e sobrenomes para garantir o anonimato dos colaboradores. 
as narrativas de resistência, ao se materializarem, através das escritas conscientes e/ou secretas, negadas, censuradas e ou públicas, transformam-se em ferramentas de conscientização, de elaboração de uma visão contra hegemônica do mundo. A escrita de si, como singular plural, permite ao sujeito, em processo de reflexividade biográfica, criar disposições e modos de resistir, de agir frente aos acontecimentos vividos, ressignificando-os através da escrita. (SOUZA; BALASSIANO; OLIVEIRA, 2014, p. 15)

Acreditamos que ao se narrar, ao contar histórias de si ou de outras pessoas, a partir dos discursos apreendidos e das subjetividades acionadas pelas narrativas visuais tematizadas pelos dilemas do cotidiano escolar, alunos e professores podem tomar consciência das aprendizagens, visando uma formação crítica, eminentemente qualitativa, porque as negociações de "lá e cá" se configuram de maneira relacional, ressignificando os atos de falar, para o outro, e de escutar, o outro. Fazendo uma analogia para explicitar essa relação, no contexto de parâmetros visuais, podemos dizer que seria uma maneira de "mostrar" (falar) e perceber (ouvir) pela imagem, ou com imagens.

1. Primeiro meme "causo": fragmentação e hierarquia disciplinar.

Figura 2 - Meme satirizando a área de conhecimento das ciências humanas.

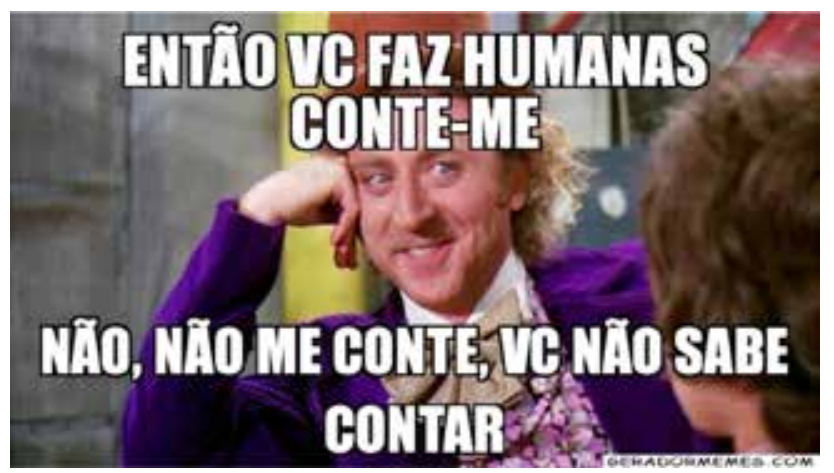

Fonte: Disponível em: <http://vestibulandoansioso. com/humor/10-frases-que-todo-vestibulando-de -humanas-escuta/>. Acesso em: 20 jul. 2017.
A imagem (figura 2) me fez recordar uma situação de constrangimento pela qual passei no ano passado, por ser estudante do curso de Licenciatura em Artes Visuais. Em uma reunião de colegas da faculdade, onde haviam estudantes do curso graduação em arquitetura, design de moda e eu, das artes, quando um dos colegas perguntou quantos semestres faltavam para eu concluir o curso, imediatamente ele mesmo completou o pensamento dizendo que eu não saberia responder à pergunta fazendo um cálculo mental, somente desenhando. Todos que estavam lá riram, inclusive eu, da piada que eu havia me tornado naquele momento. Claro que eu sei que essa piada não é novidade entre os estudantes, que por relapso (sic) reproduzem discursos historicamente construídos, demarcando as áreas de conhecimento como aquelas de grande prestígio destinadas à elite e outras tidas como subjugadas, destinadas aos menos abastados economicamente $e$ intelectualmente falando. Por outro lado, eu me pergunto o que eu tenho feito para mudar essa situação, já que também me vejo reproduzindo esses estereótipos. (V. A.)

Ao analisarmos o depoimento da aluna V. A., construído a partir da interação com um "meme" (figura 2), é possivel relacionar aspectos eminentes das discussões sobre currículo feitas por Nilda Alves (2009, p. 2). A autora é incisiva, ao constatar o seguinte:

Vamos reconhecer, para começar, que a organização curricular que temos hoje, em disciplinas - nas quais as teóricas sempre têm precedência sobre as práticas, quando entramos em contato com aquilo que é chamado 'realidade' - foi estruturada sob o período napoleônico na França, ou seja, em inícios do século XIX. [...] Nossa reforma universitária, desenvolvida durante a ditadura militar, criou e aprofundou esta estrutura departamental/disciplinar, com hierarquias intensas entre as diversas áreas do conhecimento. 
A partir dessa provocação, podemos inferir que as práticas curriculares vigentes no sistema educacional brasileiro, incluindo 0 ensino superior, ainda são pautadas em tradições cartesianas que separam o conhecimento por áreas especializadas e continuam respondendo a uma demanda classista, na promoção desigual de políticas públicas que ainda favorecem pequenas elites e apartam grandes grupos populacionais da possibilidade de ascensão ao ensino superior. No que se refere aos cursos de licenciatura, essa realidade apresenta um abismo ainda maior. A necessidade de alcançar padrões de produtividade e competitividade mercadológica em termos de formação superior, associada a uma desvalorização da carreira docente, comprometem, de várias maneiras, a qualidade do ensino, além de inibir o fluxo de candidatos atraídos pela carreira docente, porque não conseguem projetar a possibilidade de exercer a profissão com dignidade.

2. Segundo meme "causo": a mercantilização do ensino.

Figura 3 - Meme satirizando os cursos de ensino superior.

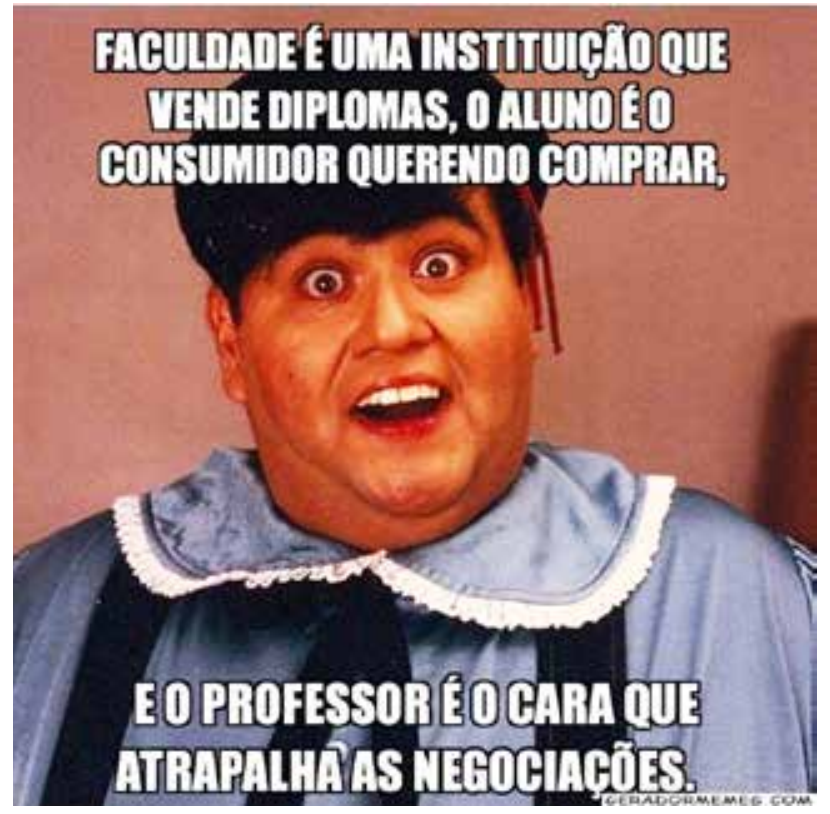

Fonte: Disponível em: <http://geradormemes.com/ meme/dvcxdn>. Acesso em: 04 jul. 2017.
Ao ver e analisar esse meme (figura 3), eu o associo a uma realidade no nosso sistema educacional brasileiro, o verdadeiro comércio de diplomas que muitas faculdades passaram a fazer. Antes de iniciar os estudos aqui na UFG, cursei, mas não concluí a graduação em uma faculdade particular. Lá, vi muitas vezes situações desse tipo. Os alunos se comportavam como se a instituição tivesse a obrigação de "aliviar" a barra deles com as cobranças dos estudos, só porque estavam pagando. E em alguns casos, os gestores realmente tentavam "aliviar" os conflitos, pedindo que os professores relevassem o descompromisso de alguns alunos, só para não perder o pagamento da mensalidade. É uma vergonha, mas, infelizmente, isso acontece. Infelizmente, não é só uma realidade limitada a uma instituição particular, vejo acontecer aqui também, mas a situação é apresentada com outra roupagem. Por exemplo, alunos que não sabem aproveitar a oportunidade de estar estudando em uma universidade pública e não se esforçam para serem aprovados. (P. M.)

Os embates diários vividos no cotidiano do ensino superior ficam evidentes em mais um "causo" da vida real narrado pela discente P. M. Sua narrativa aborda pontos críticos e consequentemente delicados, que envolvem as noções de currículo e ensino superior, em um grande imbróglio conceitual, ideológico e mercadológico. A mercantilização do ensino é um fenômeno sistêmico que tem crescido principalmente pela dificuldade de acesso ao ensino público de qualidade, pela escassez de cursos (situação comum em regiões distantes dos grandes centros do país) ou, ainda, pelo déficit de aprendizagem, fenômeno comum na educação básica. Esses fatores impossibilitam ou desencorajam os indivíduos a dar continuidade aos seus estudos, em universidades públicas, até pouco tempo frequentadas predominantemente por alunos oriundos de famílias 
com poder aquisitivo e com uma boa formação básica em instituições privadas.

Em um estudo intitulado "A mercantilização do ensino superior", Oliveira e Takada (2014), analisam as condições atuais das instituições de ensino superior privadas que têm proliferado de maneira significativa, desde a segunda metade dos anos de 1990, devido ao incentivo da política de privatização proposta pelo Governo Federal. Segundo os autores:

ingressar em uma Instituição de Ensino Superior, ainda continua sendo uma das principais formas de ascensão social. Pessoas de todas as idades buscam conhecimento e uma posição na sociedade através da graduação, pós-graduação, cursos de extensão, etc. No entanto, nos últimos tempos, é evidente o grande aumento no número de Instituições de Ensino Superior Privado no país, que por meio de uma propaganda e marketing agressivo, prometem aos futuros graduados um fácil acesso ao mercado de trabalho, com altas remunerações e status social. (OLIVEIRA; TAKADA, 2014, p. 721)

O panorama apresentado pelos autores é alarmante e provoca impactos de ordem estrutural, se analisados em termos de currículo, pois a sua materialização se efetiva cotidianamente nas estratégias desenvolvidas por profissionais da educação e, especialmente, por alunos cuja expectativa é integrar os conhecimentos adquiridos no âmbito do ensino formal às demandas sociais/profissionais contemporâneas. Diante desse panorama nos questionamos: que significados atribuímos aos processos de integração curricular diante das contradições e da potência dessa entidade "abstrata" chamada mercado? Que critérios são utilizados para selecionar os conteúdos curriculares, tendo em vista as forças que confrontam as instituições de ensino com as pressões do capitalismo? Como, no processo de avaliação dessas instituições por instâncias do governo, essas questões são tratadas?

A adoção de concepções curriculares alter- nativas visando subverter a lógica capitalista, tem se tornado aspecto central de estudos e pesquisas sobre o currículo e as pedagogias culturais. Educadores compromissados com o tema reconhecem a existência de um consenso, principalmente entre os jovens, de que as instituições escolares estão defasadas/distantes dessas demandas, são pouco atraentes e não conseguem oferecer uma formação compatível com a realidade contemporânea. Entraves avolumam-se, quando essas "instituições/máquinas" de produzir diplomas são exigidas a integrar, mesmo que precariamente, ensino, pesquisa e extensão. Um ensino superior articulado com base nesse tripé é considerado demasiadamente caro no contexto de uma mercantilização que não comporta um ensino de qualidade e muito menos a pesquisa e a extensão.

3. Terceiro meme "causo": indisciplina escolar, de quem é a culpa?

Figura 4 - Meme satirizando a indisciplina no contexto escolar.

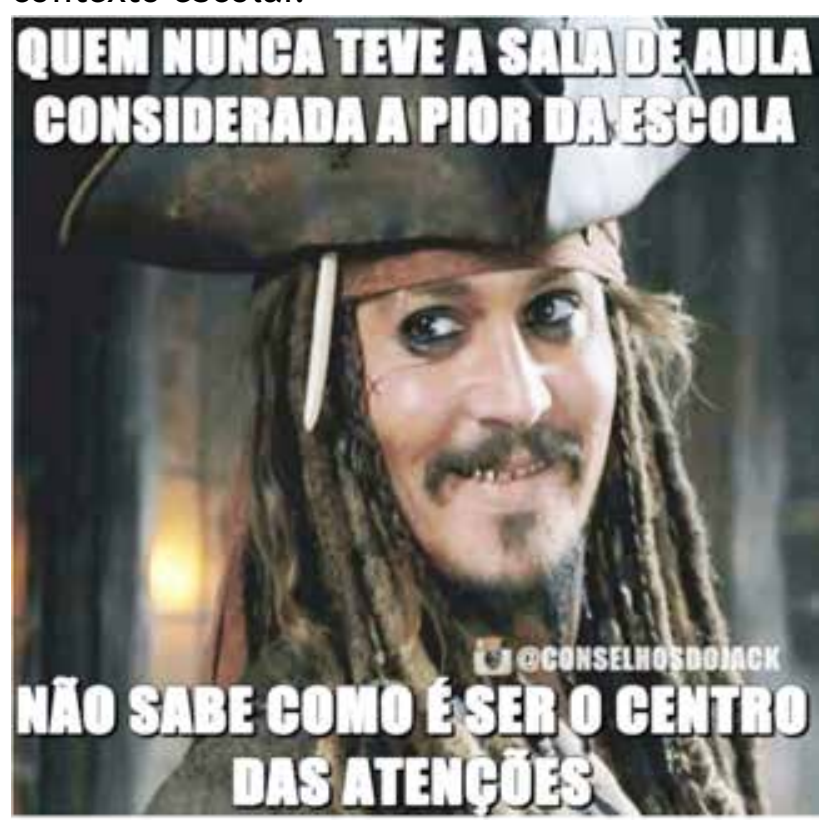

Fonte: Disponivel em: <http://vmemes.com/salade-aula/>. Acesso em: 04 jul. 2017.

Esta imagem me traz lembranças do meu tempo de aluno no ensino fundamental. $\mathrm{Na}$ 
época, ainda se chamava quinta série, mas hoje mudou para sexto ano. Eu estudava na pior sala de aula de uma escola pública, localizada em uma área periférica de Goiânia. Uma vez, um colega preparou uma bomba caseira e estourou na hora do intervalo. $O$ barulho foi tão forte que até a vizinhança saiu de casa para ver o que havia acontecido. o pior de tudo era que eu também fazia parte do grupinho desse colega e apesar de não ter envolvimento nesse episódio, fui suspenso das aulas. Todos os professores criticavam e reclamavam da turma que ficou conhecida como a turma da pesada. Muitos alunos eram repetentes, o que piorava a nossa situação. Minha mãe foi chamada pela direção para assinar um termo de compromisso por minhas ações na escola. Hoje, cursando a licenciatura, eu reflito se saberei dar aula para uma turma como aquela que eu fazia parte. Como futuro professor, me pergunto: as escolas costumam separar e formar turmas com a maioria dos alunos repetentes e fora da faixa etária? Por que a indisciplina escolar ainda é um assunto caro para a educação? (C. M.)

A perspectiva de que a escola deveria ser um lugar de formação integral dos alunos tem alimentado ideais de uma sociedade que sobrecarrega as instituições com cobranças que elas não conseguem atender, que extrapolam a capacidade de gestão e a solução de problemas como indisciplina e violência, cada vez mais corriqueiros dentro e fora delas. A concepção de currículo vigente alimenta esse ideal e o subscreve na legislação:

Art. 6o - o currículo é conceituado como a proposta de ação constituída pela seleção de conhecimentos construídos pela sociedade, expressando-se por práticas escolares que se desdobram em torno de conhecimentos escolares relevantes, permeadas pelas relações sociais, articulando vivências e saberes dos estudantes e contribuindo para o desenvolvimento de suas identidades e condições cognitivas e socioafetivas. (BRASIL, 2012, grifos nossos)
A responsabilidade da escola no sentido de desenvolver as "condições cognitivas" e "socioafetivas" dos estudantes tem gerado inúmeros descompassos, em termos de currículo e da educação formal. Casos de indisciplina dos alunos, assim como relatado por C. M., no depoimento acima, geram tensões nas relações do cotidiano escolar. Muitas vezes, a indisciplina é um reflexo da carência de condições econômicas, sociais e de lazer, nas quais os alunos vivem, e mesmo da violência vivida por eles no núcleo familiar. Construir relações articulando as vivências e os saberes dos estudantes para a sua formação é tarefa complexa, que deve ser compartilhada por todos, pais, escola e sociedade, imbuídos do compromisso de transformar práticas excludentes em ações inclusivas e colaborativas.

4. Quarto meme "causo": educação frente à emergência tecnológica.

Figura 5 - Meme satirizando os processos de ensino e de aprendizagem escolar.

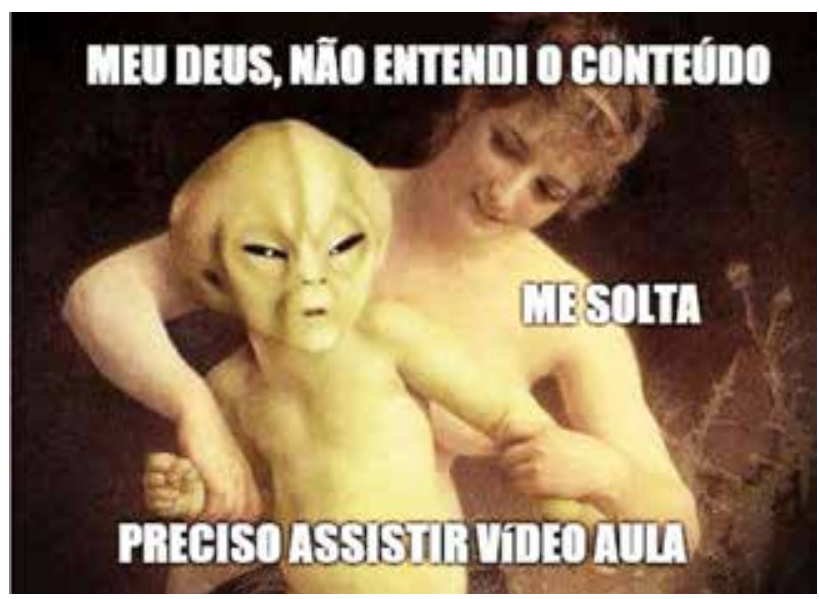

Fonte: Disponivel em: <https://onsizzle.com/i/ meudeus-naoentendio-conteudo-mesolta-precisoassistir-video-aula-curta-me-solta-431733>. Acesso em: 04 jul. 2017.

Esse meme (figura 5) faz graça com um caso que é muito frequente entre os alunos. Eu mesma busco os canais do YouTube para estudar e tirar as dúvidas que os professores não conseguem tirar. Não estou dizendo que a culpa 
de eu não aprender a matéria é só responsabilidade do professor, mas, em muitos momentos, eles realmente não ensinam ou não conseguem explicar de uma forma mais simples, pra que a gente possa entender. As videoaulas que a gente encontra na internet são muito boas $e$, às vezes, melhores que muitas aulas de professores com mestrado e doutorado. Vejo os conteúdos das videoaulas e de outros suportes de tecnologia como importantes contribuições para o nosso processo de aprendizagem, pois só a educação formal não consegue suprir as nossas necessidades. (A. S.)

Eis mais uma questão para pensarmos em termos de política educacional e que tem impacto na integralização do currículo. No mundo contemporâneo, continuamente nos vemos diante de situações-problema, demandas cotidianas decorrentes da condição tecnológica na qual estamos submersos. Vale ressaltar que, com frequência, essas demandas são incompatíveis com a política educacional das instituições, que apresentam dificuldades em acompanhar as transformações tecnológicas, por diversos motivos, a falta de recursos financeiros é apenas um deles.

As concepções de conhecimento, tal como as estamos produzindo, implicam a ampliação de enfoques para além dos contextos vinculados estritamente às instituições educativas, exigindo engajamento e diligência para discutir essas práticas a partir das insurgências culturais e não apartadas delas, ou seja, de maneira estanque.

No contexto do ensino de arte, mas não somente nele, Miranda (2015) chama a atenção para as ricas possibilidades de aprendizagem que os acontecimentos diários, do cotidiano, podem revelar. $\mathrm{O}$ autor diz:

tentamos chamar a atenção para a possibilidade de produzir uma educação que trabalhe com a arte contemporânea e a cultura visual mediante a produção de acontecimentos como ações participativas, como testemunhos abertos, como arquivos em construção. Acontecimentos que abram a educação para os olhares múltiplos e críticos, que permitam abordar suas contingências com a inclusão de referências próprias e das experiências particulares de cada biografia. Talvez, assim, possamos encontrar mais caminhos para criar conhecimentos e produzir aprendizagens relevantes. (MIRANDA, 2015, p. 162)

Motivados por esse pensamento, damos ênfase ao depoimento de A. S., quando declara:

"As videoaulas que a gente encontra na internet são muito boas e, às vezes, melhores que muitas aulas de professores com mestrado $e$ doutorado. Vejo os conteúdos das videoaulas e de outros suportes de tecnologia como importantes contribuições para o nosso processo de aprendizagem, pois só a educação formal não consegue suprir as nossas necessidades".

É imperativo reconhecer que são muitas as interfaces passíveis de gerar aprendizagem. O ensino formal, no contexto que vivemos na contemporaneidade, é apenas uma dessas inúmeras possibilidades. Há algum tempo, professores dispõem do suporte das mídias digitais para planejar e implementar abordagens e práticas de ensino colaborativas, embora, muitas vezes, não tenham se dado conta das possibilidades pedagógicas que essas abordagens oferecem e possibilitam.

\section{Considerações finais}

Concluindo este texto, trazemos as provocações feitas por Alves (2010) sobre a importância das micropolíticas curriculares instauradas muitas vezes de forma silenciosa no bojo das macroações públicas. De acordo com a autora:

[...] vemos as políticas, necessariamente, como práticas coletivas dentro de um campo qualquer no qual há, sempre, lutas entre posições diferentes e, mesmo, contrárias. Desta maneira, não vemos como 'políticas' somente as ações 
dos grupos hegemônicos na sociedade, embora estes produzam ações que são mais visiveis. Os grupos não hegemônicos, em suas ações, produzem políticas que, muitas vezes, não são visiveis aos que analisam 'as políticas' porque estes foram formados para enxergar, exclusivamente, o que é hegemônico com o que aprenderam com o modo de pensar hegemônico. (ALVES, 2010, p. 49, grifos da autora)

Fisgados por esse "pensar/construir currículo" que subverte a lógica hegemônica, chamamos a atenção para a força educativa dos acontecimentos ordinários da vida, dos mo-

\section{Referências}

AGUIRRE, Imanol. Cultura visual, política da estética e educação emancipadora. In: MARTINS, Raimundo; TOURINHO, Irene. (Orgs.). Educação da cultura visual: conceitos e contextos. Santa Maria, RS: Editora UFSM, 2011. p. 69-111.

ALVES, Nilda. Currículo, docência e escola. Revista Eletrônica Espaço do Currículo - Sessão especial, João Pessoa-PB, v. 1, n. 2, p. 07-10, mar. 2009. Disponivel em: <http://periodicos.ufpb.br/ojs/index. $\mathrm{php} / \mathrm{rec} /$ issue/view/439/showToc $>$. Acesso em: 19 jul. 2017.

Redes educativas "dentrofora" das escolas, exemplificadas pela formação de professores. In: DALBEN, Ângela et al. (Orgs.). Convergências e tensões no campo da formação e do trabalho docente. Belo Horizonte: Autêntica, 2010. p. 49-66.

APPLE, Michael W. Ideologia e currículo. 3. ed. Porto Alegre: Artmed, 2006.

BERNSTEIN, Basil. Classes e pedagogia: visivel e invisivel. Cadernos de Pesquisa, n. 49, p. 36-42, mai. 1984.

BRASIL. Diretrizes Curriculares Nacionais para o Ensino Médio. Brasília, DF: MEC, 2012.

COSTA, Marisa Vorraber; SILVEIRA, Rosa Hessel; SOMMER, Luis Henrique. Estudos culturais, educação e pedagogia. Revista Brasileira de Educação, $n$. 23, p. 36-61, mai./jun./jul./ago. 2003. Disponível em: mentos cotidianos, pois eles têm muito a nos ensinar. Nesse sentido, os discursos deflagrados pelos memes de internet, sobre problemas e demandas educacionais, nos ajudam a perceber que eles constituem e veiculam as vozes de sujeitos que, indignados e inconformados, narram a condição letárgica em que vivemos. Para sair dessa condição letárgica, é necessário criar outros espaços, criar abordagens alternativas que nos ajudem a confrontar e a ressignificar a nossa ação como educadores e aprendizes.

<http://www.scielo.br/pdf/rbedu/n23/n23a03>. Acesso em: 20 jul. 2017.

DAWKINS, Richard. 0 gene egoísta [1976]. São Paulo: Companhia das Letras, 2007.

DIAS, Belidson. O cotidiano espetacular e a arte educação. In: MARTINS, Raimundo; MARTINS, Alice F. (Orgs.). Cultura visual e ensino de arte: concepções e práticas em diálogos. Pelotas, RS: Ed. UFPel, 2014. p. 43-59.

DIDI-HUBERMAN, Georges. Quando as imagens tocam o real. Revista Pós, Escola de Belas Artes, Universidade Federal de Minas Gerais, v. 2, n. 4, p. 204219, 2012. Disponivel em: <https://www.eba.ufmg. br/revistapos/index.php/pos/article/view/60/62>. Acesso em: 19 jul. 2017.

GOODSON, Ivor. Currículo, narrativa e o futuro social. Revista Brasileira de Educação, Rio de Janeiro, v. 12 , n. 35 , p. 241-252, mai./ago. 2007. Disponível em: <http://www.scielo.br/pdf/rbedu/v12n35/ a05v1235.pdf>. Acesso em: 10 ago. 2017.

MARTINS, Raimundo. Narrativas visuais: imagens, visualidades e experiência educativa. Revista do Programa de Pós-Graduação em Arte da UnB, Brasília, v. 8, n. 1, p. 33-39, jan./jun. 2009.

MIRANDA, Fernando. FORA DE CONTROLE: acontecimentos e aprendizagens na cultura visual e na arte contemporânea. In: MARTINS, Raimundo; TOU- 
RINHO, Irene. (Orgs.). Educação da cultura visual aprender... pesquisar... ensinar... Santa Maria, RS: Editora UFSM, 2015. p. 147-164.

NASCIMENTO, Erinaldo. Singularidades da educação da cultura visual nos deslocamentos das imagens e das interpretações. In: MARTINS, Raimundo; TOURINHO, Irene. (Orgs.). Educação da cultura visual: conceitos e contextos. Santa Maria, RS: Ed. da UFSM, 2011. p. 209-226.

NOGUERA-RAMÍREZ, Carlos Ernesto. 0 governamento pedagógico: da sociedade do ensino para a sociedade da aprendizagem. 2009. 266 f. Tese (Doutorado em Educação) - Programa de Pós-Graduação em Educação, Faculdade de Educação, Universidade Federal do Rio Grande do Sul, Porto Alegre, 2009.

OLIVEIRA, Murilo Delanhesi de.; TAKADA, Mário Yudi. A mercantilização do ensino superior. Colloquium Humanarum, v. 11, n. Especial, p. 721-728, jul./dez. 2014. Disponível em: <http://www.unoeste.br/site/ enepe/2014/suplementos/area/Humanarum/Educa\%C3\%A7\%C3\%A30/A\%20MERCANTILIZA\%C3\%87\%C3\%830\%20DO\%20ENSINO\%20SUPERIOR.pdf>. Acesso em: 20 jul. 2017.

PRADA, Juan Martín. La creatividad de la multitud conectada y el sentido del arte en el contexto de la Web 2.0. Estudios Visuales 5, Centro de Documentación y Estudios Avanzados de Arte Contemporáneo, Murcia, p. 66-79, ene. 2008. Disponível em: <http:// estudiosvisuales.net/revista/pdf/num5/prada 20. pdf>. Acesso em: 10 ago. 2017.

SANTIAGO, Silviano. Ora (direis) puxar conversa! Belo Horizonte: Editora UFMG, 2006.

SILVA, Tomaz Tadeu da. Teoria cultural e educação: um vocabulário crítico. Belo Horizonte: Autêntica, 2000.

SHIFMAN, Limor. Memes in digital culture. Massachusetts: MIT Press, 2014.

SOUZA, Elizeu Clementino de. Histórias de vida e formação de professores. In: BRASIL, Ministro da Educação; TV Escola/SEED/Salto para o Futuro. Histórias de vida e formação de professores, Boletim 1, p. 3-14, mar. 2007. Disponível em: <http://cdnbi. tvescola.org.br/resources/VMSResources/contents/document/publicationsSeries/104711Historias2. pdf>. Acesso em: 22 jul. 2017. ;; BALASSIANO, Ana Luiza G.; OLIVEIRA, Anne -Marie M. Apresentação. In: (Orgs.) Escrita de si, resistência e empoderamento. Curitiba: CRV, 2014. p. 13-23.

YÚDICE, George. A conveniência da cultura. Belo Horizonte: Editora UFMG, 2005.

Recebido em: 16.08.2017

Aprovado em: 02.11.2017

Clícia Coelho é Doutoranda em Arte e Cultura Visual pela Universidade Federal de Goiás (UFG). Mestre em Artes Visuais pela Universidade Federal da Paraíba (UFPB). Docente do Departamento de Educação da Universidade Federal do Amapá (UNIFAP). Telefone institucional: (62) 3521-1159. e-mail: cliciacoelho@gmail.com

Programa de Pós-Graduação em Arte e Cultura Visual (PPGACV), Faculdade de Artes Visuais. Universidade Federal de Goiás-UFG. Endereço: Avenida Esperança s/n. Campus Samambaia - Goiânia/GO, 74690-900, Telefone: (62) $3521-1159$. 